\title{
SKRIPSI
}

\section{ANALISIS HUBUNGAN ANTARA INTENSITAS KEBISINGAN DENGAN KEJADIAN HIPERTENSI PADA MASYARAKAT DI PEMUKIMAN KELURAHAN 26 ILIR KECAMATAN BUKIT KECIL KOTA PALEMBANG}

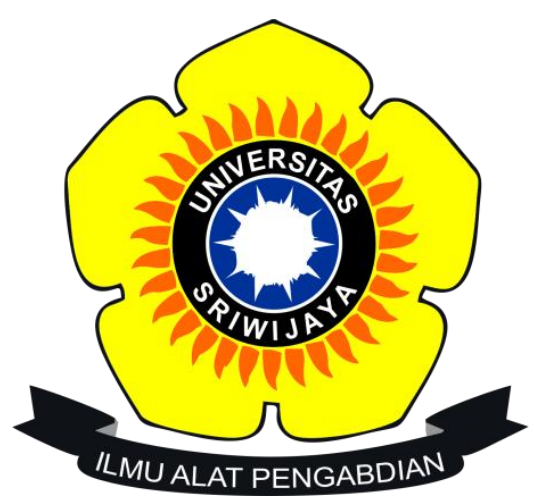

\author{
OLEH \\ NAMA : NAHDHA SYARIFAH \\ NIM : 10031281722035
}

PROGRAM STUDI KESEHATAN LINGKUNGAN (S1)

FAKULTAS KESEHATAN MASYARAKAT

UNIVERSITAS SRIWIJAYA 


\section{SKRIPSI}

\section{ANALISIS HUBUNGAN ANTARA INTENSITAS KEBISINGAN DENGAN KEJADIAN HIPERTENSI PADA MASYARAKAT DI PEMUKIMAN KELURAHAN 26 ILIR KECAMATAN BUKIT KECIL KOTA PALEMBANG}

Diajukan untuk memenuhi salah satu syarat memperoleh gelar (S1) Sarjana Kesehatan Lingkungan pada Fakultas Kesehatan Masyarakat Universitas Sriwijaya

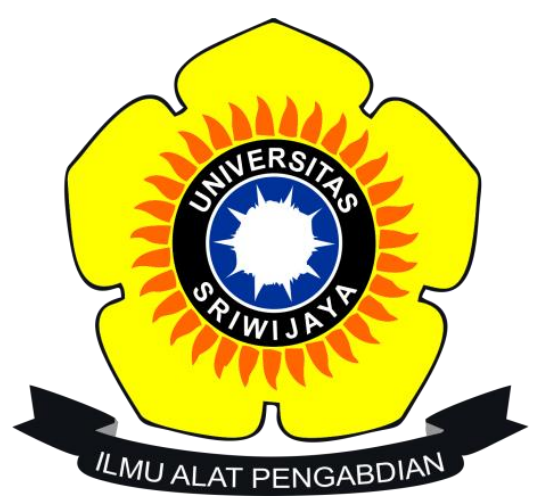

OLEH

$\begin{array}{ll}\text { NAMA } & : \text { NAHDHA SYARIFAH } \\ \text { NIM } & : 10031281722035\end{array}$

PROGRAM STUDI KESEHATAN LINGKUNGAN (S1)

FAKULTAS KESEHATAN MASYARAKAT

UNIVERSITAS SRIWIJAYA 


\title{
PROGRAM STUDI KESEHATAN LINGKUNGAN \\ FAKULTAS KESEHATAN MASYARAKAT \\ UNIVERSITAS SRIWIJAYA
}

Skripsi, 18 Juni 2021

Nahdha Syarifah; Dibimbing oleh Dwi Septiawati, S.KM., M.KM

Analisis Hubungan Antara Intensitas Kebisingan dengan Kejadian Hipertensi
pada Masyarakat di Pemukiman Kelurahan 26 Ilir Kecamatan Bukit Kecil
Kota Palembang

xvii, 127 halaman, 40 tabel, 12 gambar, 5 lampiran

\begin{abstract}
ABSTRAK
Hipertensi adalah suatu peningkatan abnormal dari tekanan darah dalam pembuluh darah arteri yang mengangkut darah dari jantung dan memompa keseluruh jaringan dan organ-organ tubuh secara terus-menerus. Intensitas kebisingan dapat menjadi faktor risiko terjadinya kejadian hipertensi pada masyarakat. Penelitian ini bertujuan untuk mengetahui hubungan antara intensitas kebisingan dengan kejadian hipertensi pada masyarakat di pemukiman Kelurahan 26 Ilir Kecamatan Bukit Kecil Kota Palembang. Penelitian ini merupakan penelitian kuantitatif dengan desain studi cross sectional dengan teknik pengambilan sampel secara Purposive Sampling sebanyak 105 responden. Alat ukur yang digunakan dalam penelitian ini adalah Mini InScience Pro SQ-100 Sound Level Meter dan Aneroid Sphygmomanometer. Data dianalisis secara univariat, bivariat dengan menggunakan uji Chi Square, dan multivariat dengan menggunakan uji regresi logistik ganda dan model faktor risiko. Hasil bivariat menunjukan ada hubungan antara intensitas kebisingan ( $p$-value 0,000$)$, usia ( $p$-value 0,032$)$, aktivitas fisik ( $p$ value 0,038), jarak rumah ( $p$-value 0,004), barrier ( $p$-value 0,001), dan tidak ada hubungan antara riwayat keluarga ( $p$-value 0,828), merokok ( $p$-value 0,782$)$, serta keberadaan tanaman hias ( $p$-value 0,058 ) terhadap kejadian hipertensi, dan pada analisis multivariat menunjukkan ada hubungan yang signifikan antara intensitas kebisingan dengan kejadian hipertensi pada masyarakat ( $p$-value $=0,013$ ) setelah dikontrol dengan variabel usia, riwayat keluarga, jarak rumah, dan barrier. Dapat disimpulkan bahwa masyarakat yang terpapar kebisingan tinggi secara terus menerus dapat meningkatkan risiko untuk mengalami hipertensi. Saran yang dapat diberikan adalah diharapkan masyarakat rutin beraktivitas fisik setidaknya 10 menit setiap harinya, menambah barrier serta menanam tanaman hias.
\end{abstract}

Kata Kunci : Masyarakat Pemukiman, Intensitas Kebisingan, Hipertensi

Kepustakaan : $142(1975-2021)$ 
ENVIRONMENTAL HEALTH

FACULTY OF PUBLIC HEALTH

SRIWIJAYA UNIVERSITY

Skripsi, 18 Juni 2021

Nahdha Syarifah; Guided by Dwi Septiawati, S.KM., M.KM

Analysis of the Relationship Between Noise Intensity with the Incidences of Hypertension in Communities in the Settlement Of 26 Ilir Sub-District, Bukit Kecil District, Palembang City

xvii, 127 pages, 40 tables, 12 pictures, 5 attachments.

\begin{abstract}
Hypertension is an abnormal increase in blood pressure inside the arteries that carries blood away from the heart and pump it to all the body tissues and organs continuously. Noise intensity can be a risk factor for the incidences of hypertension in the community. This research aims to determine the relationship between noise intensity and the incidences of hypertension in the community in the settlement of 26 Ilir Sub-District, Bukit Kecil District, Palembang City. This research is a quantitative study using a cross sectional study design with purposive sampling technique to 105 respondents. The measuring instruments that used in this study were the Mini InScience Pro SQ-100 Sound Level Meter and Aneroid Sphygmomanometer. The data were analyzed by univariate, bivariate using $C h i$ Square test, and multivariate using multiple logistic regression tests with risk factors model.The bivariate results showed that there is a relationship between noise intensity ( $p$-value 0,000$)$, age ( $p$-value 0,032$)$, physical activity ( $p$-value 0,038$)$, home distance ( $p$-value 0,004$)$, barrier ( $p$-value 0,001$)$ and there is no relationship between family history ( $p$-value 0,828$)$, smoking ( $p$-value 0,782$)$, the presence of ornamental plants ( $p$-value 0,058$)$ to the incidence of hypertension, and the multivariate analysis showed that there is a significant relationship between noise intensity and the incidences of hypertension in the community ( $p$-value 0,013 ) after controlled by variables of age, family history, house distance, and barrier. The conclusion of this research is that people who are exposed to high noise continuously can increase their risk of developing hypertension. The suggestions that can be given from this research is that it is hoped that communities will routinely do physical activity for at least 10 minutes every day, increase the amounts of barriers and plant the ornamental plants.
\end{abstract}

Keywords : Communities, Noise Intensity, Hypertension

Bibliography : 142 (1975-2021) 


\title{
ANALISIS HUBUNGAN ANTARA INTENSITAS KEBISINGAN DENGAN KEJADIAN HIPERTENSI PADA MASYARAKAT DI PEMUKIMAN KELURAHAN 26 ILIR KECAMATAN BUKIT KECIL KOTA PALEMBANG
}

\author{
SKRIPSI \\ Diajukan Untuk Memenuhi Salah Satu Syarat \\ Memperoleh Gelar Sarjana Kesehatan Lingkungan \\ Oleh : \\ NAHDHA SYARIFAH \\ NIM. 10031281722035
}

Mengetahui

Dekan Fakultas Kesehatan Masyarakat

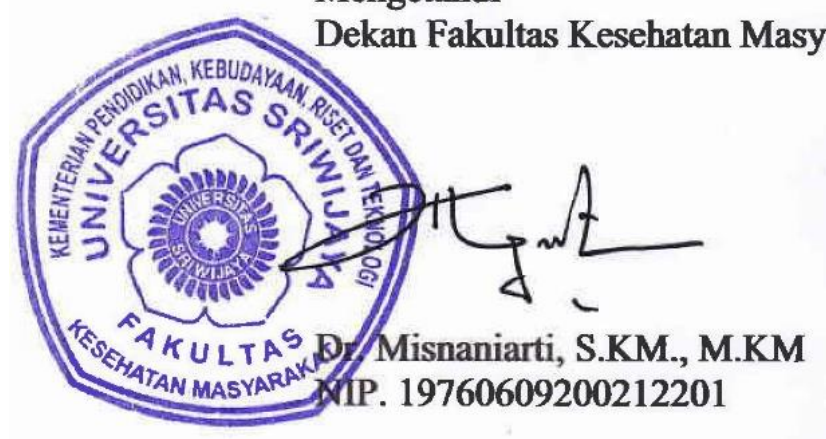

Indralaya, 18 Juni 2021

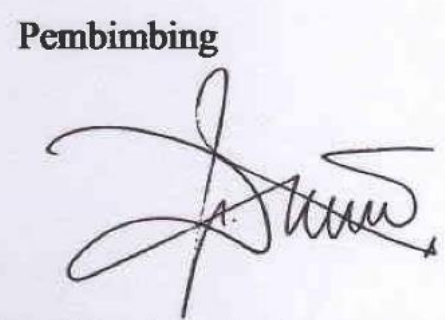

Dwi Septiawati, S.KM.,M.KM

NIP. 198912102018032001 


\section{HALAMAN PERSETUJUAN}

Karya tulis ilmiah berupa skripsi ini dengan judul "Analisis Hubungan Antara Intensitas Kebisingan Dengan Kejadian Hipertensi pada Masyarakat di Pemukiman Kelurahan 26 Ilir Kecamatan Bukit Kecil Kota Palembang” telah dipertahankan di hadapan Tim Penguji Skripsi Fakultas Kesehatan Masyarakat Universitas Sriwijaya pada Tanggal 18 Juni 2021.

Indralaya, 18 Juni 2021

Tim Penguji Skripsi

\section{Ketua:}

1. Elvi Sunarsih, S.K.M., M.Kes.

NIP. 197806282009122004

\section{Penguji:}

1. Desri Maulina Sari, S,Gz., M.Epid NIP. 198612112019032009

2. Anggun Budiastuti, S.KM., M.Epid NIP. 19900729201903202

3. Dwi Septiawati, S.KM., M.KM.

NIP. 198912102018032001

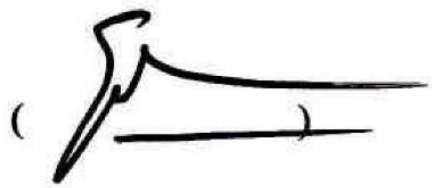

Mengetahui

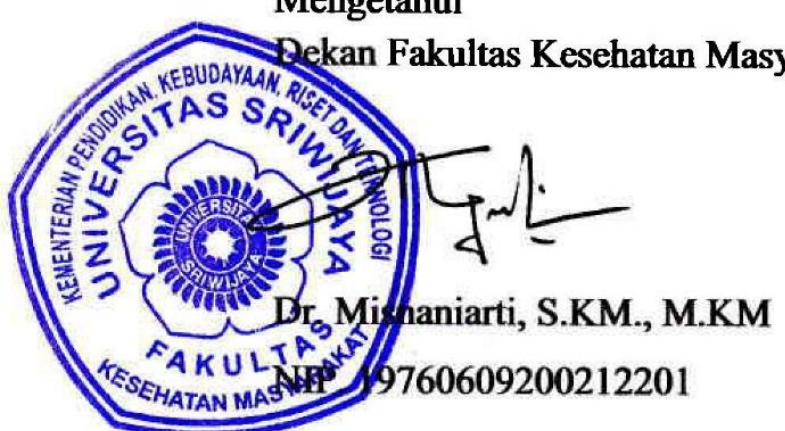

Koordinator Program Studi Kesehatan Lingkungan

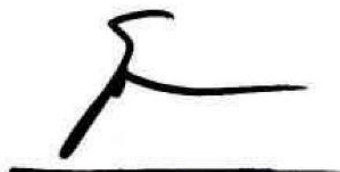

Elvi Sunarsih, S.KM., M.Kes NIP. 197806282009122004 


\section{LEMBAR PERNYATAAN BEBAS PLAGIARISME}

Saya dengan ini menyatakan bahwa skripsi ini dibuat dengan sejujurnya dengan mengikuti kaidah Etika Akademik FKM Unsri serta menjamin bebas plagiarisme. Bila kemudian diketahui saya melanggar Etika Akademik maka saya bersedia dinyatakan tidak lulus/gagal.

Indralàya, 18 Mei 2021

Yang Bersangkutan,

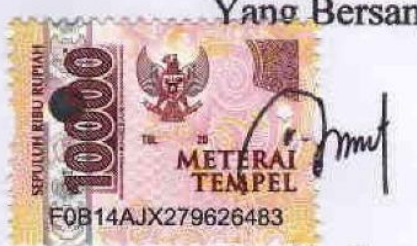

Nahdha Syarifah

NIM. 10031281722035 


\section{DAFTAR RIWAYAT HIDUP}

\section{Data Pribadi}

Nama

NIM

Jenis Kelamnin

Agama

Tempat Tanggal Lahir

Alamat

No. Telpon/HP

Email

Riwayat Pendidikan

2005-2011

2011-2014

2014-2017

2017-2021

Riwayat Organisasi

2014-2017

2019-Sekarang
: Nahdha Syarifah

: 10031281722035

: Perempuan

: Islam

: Palembang, 13 Maret 2000

: Jalan Sultan Muhammad Mansyur Lorong Alir

Gang Pelita 7, Kecamatan Ilir Barat 1, Kelurahan

Bukit Lama, Palembang

: 089634722839

: nahdhasyarifah@gmail.com

: SD Negeri 162 Palembang

: SMP Negeri 2 Palembang

: SMA Negeri 2 Palembang

: Program Studi Kesehatan Lingkungan, Fakultas

Kesehatan Masyarakat, Universitas Sriwijaya

: Anggota Paduan Suara SMAN 2 Palembang

: Anggota Hansarang Club Palembang 


\section{KATA PENGANTAR}

Puji syukur penulis tuturkan kepada Allah SWT berkat rahmat, ridho, serta karunia-Nya sehingga penulis bisa menyelesaikan skripsi yang berjudul "Analisis Hubungan Antara Intensitas Kebisingan dengan Kejadian Hipertensi pada Masyarakat di Pemukiman Kelurahan 26 Ilir Kecamatan Bukit Kecil Kota Palembang”. Penyusunan skripsi ini tidak akan terselesaikan dengan baik tanpa arahan, bimbingan, kritik, saran, dukungan dan semangat dari berbagai pihak. Oleh karena itu, penulis ingin menyampaikan terima kasih kepada semua pihak yang telah berkontribusi dalam penyelesaian Skripsi ini. Dengan rasa hormat dan kerendahan hati, penulis mengucapkan terima kasih kepada:

1. Allah SWT, yang telah memberikan nikmat kesehatan, kesempatan, keselamatan serta kelancaran dalam penyusunan skripsi ini.

2. Ibu Dr. Misnaniarti, S.KM., M.KM. selaku Dekan Fakultas Kesehatan Masyarakat Universitas Sriwijaya.

3. Ibu Elvi Sunarsih, S.K.M., M.Kes selaku Kepala Program Studi Kesehatan Lingkungan Fakultas Kesehatan Masyarakat Universitas Sriwijaya.

4. Ibu Dwi Septiawati, S.KM., M.KM. selaku Dosen Pembimbing Skripsi yang telah banyak berkontribusi baik tenaga, waktu dan pikiran dalam membimbing, mengarahkan, mendukung dan memberi semangat dalam penelitian ini.

5. Ibu Elvi Sunarsih, S.K.M., M.Kes., Bapak Dr. H.A. Fickry Faisya, S.KM., M.Kes. (Alm.), Ibu Desri Maulina Sari, S.Gz., M.Epid., dan Ibu Anggun Budiastuti, S.KM., M.Epid selaku Penguji 1, 2, dan 3 yang telah meluangkan waktunya untuk memberikan kritik dan saran sehingga skripsi ini dapat berjalan dengan lancar.

6. Kedua orang tua tercinta, Ibu dan Bapak, serta adik perempuan saya yang telah memberikan doa, semangat, nasihat, dukungan, serta ilmunya baik berupa materi maupun non-materi sehingga saya bisa menyelesaikan studi saya di Universitas Sriwijaya dengan baik.

7. Seluruh masyarakat di Kelurahan 26 Ilir yang terlibat dan bersedia menjadi responden dalam penelitian saya. 
8. Dian Puspasari, Lira Palwa S., Nadiah Khairunnisa I., Guntur Lasmana S., dan Endang Puji Retno K. yang bersedia menjadi tempat berkeluh kesah serta pemberi saran, ilmu, semangat, dan menjadi partner penelitian maupun debat selama berjalannya proses pembuatan skripsi ini.

9. Teman-teman seperbimbingan skripsi Erik Kurniawan, dan Wafiq Febri Erlianti Safitri serta teman-teman lainnya yang telah menjadi partner berbagi informasi dalam penyelesaian skripsi.

10. Teman-teman seperjuangan di bangku perkuliahan yang tidak dapat Saya sebutkan satu per satu.

Saya menyadari dalam penulisan dan penyusunan skripsi ini masih banyak kekurangan, baik dari segi sistematika bahasa dan penulisan hingga konteks isi skripsi ini. Oleh sebab itu, saya mengharapkan kritik dan saran dari pembaca yang bersifat membangun untuk penyempurnaan penulisan skripsi ini.

Indralaya, 18 Juni 2021

Penulis

Nahdha Syarifah

NIM. 10031281722035 


\section{LEMBAR PERNYATAAN PERSETUJUAN PUBLIKASI \\ TUGAS AKHIR UNTUK KEPENTINGAN AKADEMIS}

Sebagai civitas akademik Universitas Sriwijaya, saya yang bertandatangan di bawah ini :

$\begin{array}{ll}\text { Nama } & \text { : Nahdha Syarifah } \\ \text { NIM } & : 10031281722035 \\ \text { Program Studi } & : \text { Kesehatan Lingkungan } \\ \text { Fakultas } & \text { : Kesehatan Masyarakat } \\ \text { Jenis Karya Ilmiah } & \text { : Skripsi }\end{array}$

Dengan ini menyatakan menyetujui untuk memberikan kepada Fàkultas Kesehatan Masyarakat Universitas Sriwijaya Hak Bebas Royalti Noneksklusif (Non-exlucive Royalty Free Right) atas karya ilmiah saya yang berjudul :

“Analisis Hubungan Antara Intensitas Kebisingan Dengan Kejadian Hipertensi Pada Masyarakat Di Pemukiman Kelurahan 26 Ilir Kecamatan Bukit Kecil Kota Palembang".

Beserta perangkat yang ada (jika diperlukan). Dengan hak Bebas Royalti Noneksklusif ini Universitas Sriwijaya berhak menyimpan, mengalihmedia/ formatkan, mengelola dalam bentuk pangkalan data (database), merawat dan mempublikasikan tugas akhir saya selama tetap mencantumkan nama saya sebagai penulis/pencipta dan sebagai pemilik hak cipta.

Demikian pernyataan ini saya buat dengan sebenarnya.

Dibuat : di Indralaya

Pada Tanggal : 18 Juni 2021

Yang menyatakan

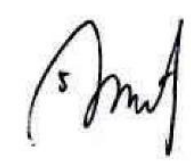

Nahdha Syarifah

NIM. 10031281722035 


\section{DAFTAR ISI}

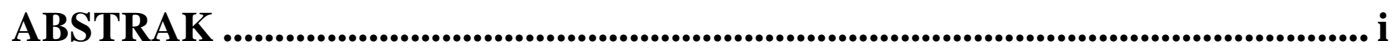

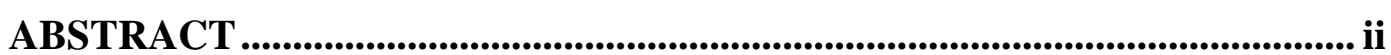

LEMBAR PENGESAHAN ........................................................................... iii

HALAMAN PERSETUJUAN .................................................................................. iii

LEMBAR PERNYATAAN BEBAS PLAGIARISME ....................................... v

DAFTAR RIWAYAT HIDUP ................................................................................. vi

KATA PENGANTAR ........................................................................................ vii

DAFTAR ISI....................................................................................................... $\mathrm{x}$

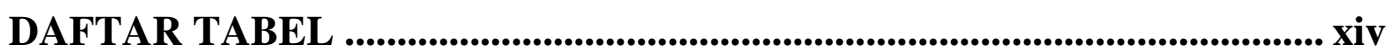

DAFTAR GAMBAR .................................................................................

BAB I PENDAHULUAN ....................................................................................... 1

$1.1 \quad$ Latar Belakang .................................................................................... 1

1.2 Rumusan Masalah .............................................................................. 4

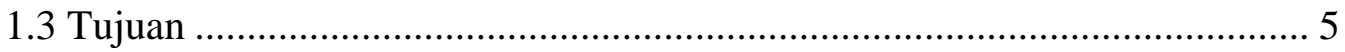

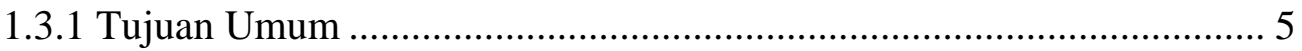

1.3.2 Tujuan Khusus ……………………………………………….... 5

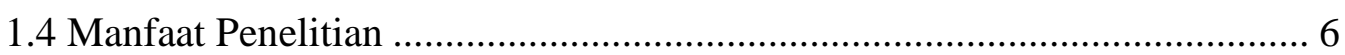

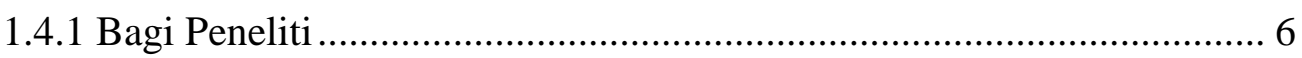

1.4.2 Bagi Fakultas Kesehatan Masyarakat ……………………………....... 6

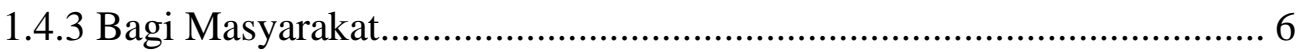

1.4.4 Bagi Pemerintah ............................................................................... 7

1.5 Ruang Lingkup Penelitian......................................................................... 7

1.5.1 Lingkup Materi................................................................................ 7

1.5.2 Lingkup Lokasi …………………………………………………….. 7

1.5.3 Lingkup Waktu.................................................................................... 7

BAB II TINJAUAN PUSTAKA........................................................................ 8

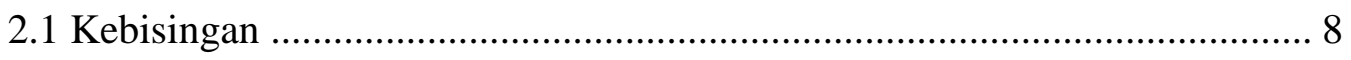

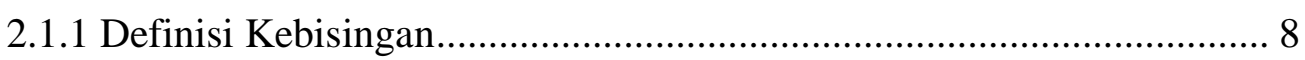


2.1.2 Jenis Kebisingan 8

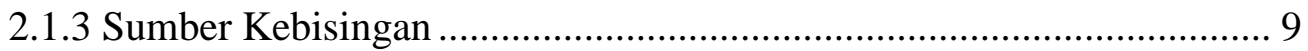

2.1.4 Standar Baku Tingkat Kebisingan ................................................... 12

2.1.5 Faktor Yang Mempengaruhi Tingkat Intensitas Kebisingan .............. 14

2.1.6 Dampak Kebisingan Lingkungan Terhadap Kesehatan ...................... 18

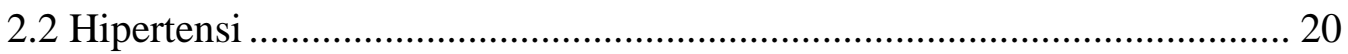

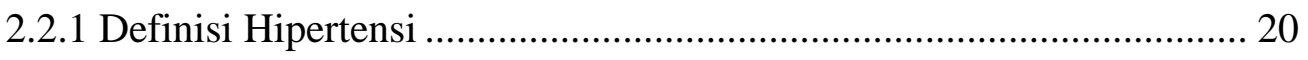

2.2.2 Klasifikasi Hipertensi................................................................. 22

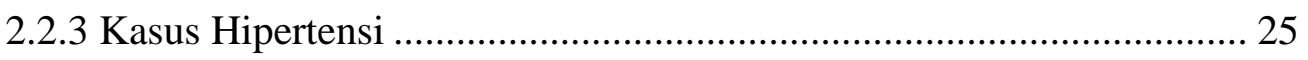

2.2.4 Faktor Risiko Hipertensi ............................................................... 25

2.3 Alur Mekanisme Biologis Kebisingan Terhadap Hipertensi ..................... 32

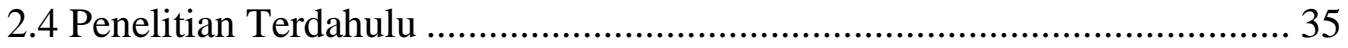

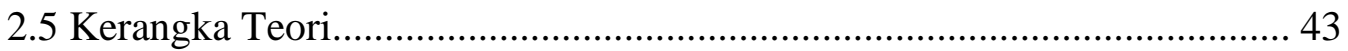

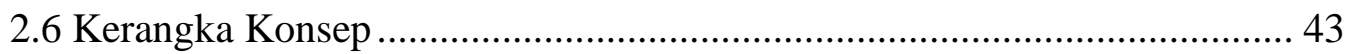

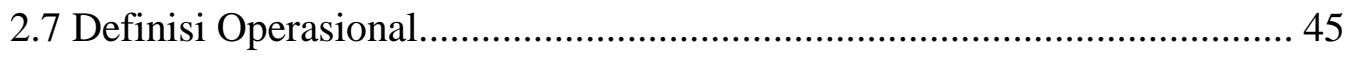

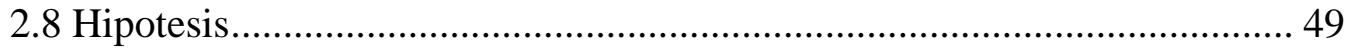

BAB III METODE PENELITIAN ..............................................................5 50

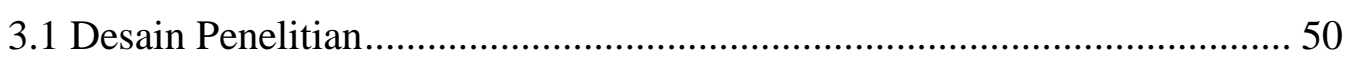

3.2 Populasi dan Sampel Penelitian ......................................................... 51

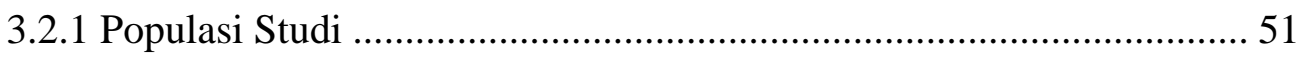

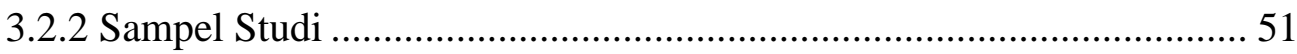

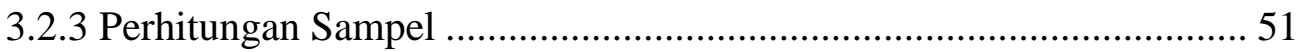

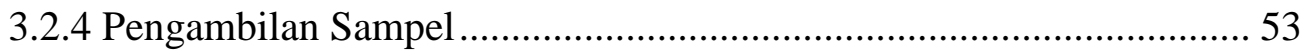

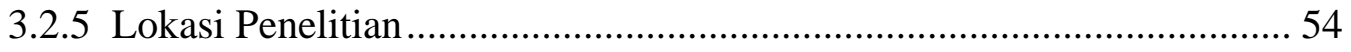

3.3 Jenis, Cara dan Alat Pengumpulan Data .................................................. 54

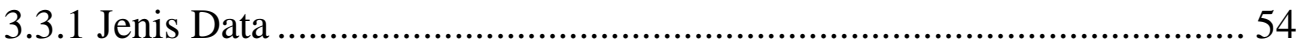




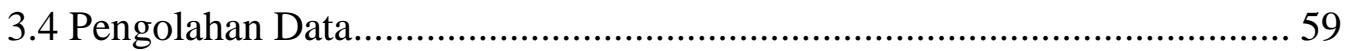

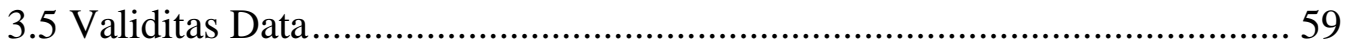

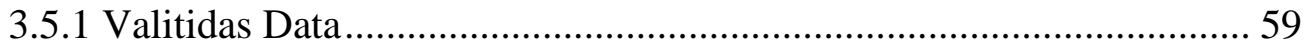

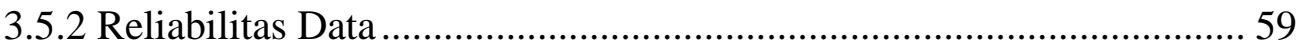

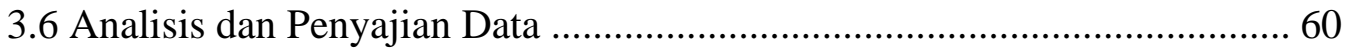

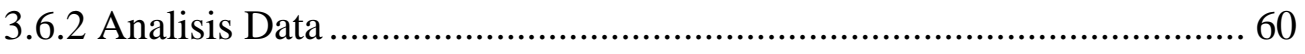

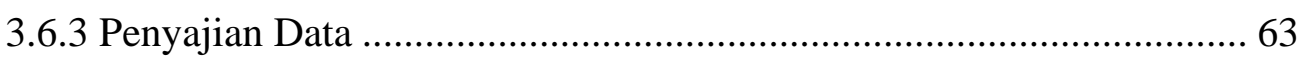

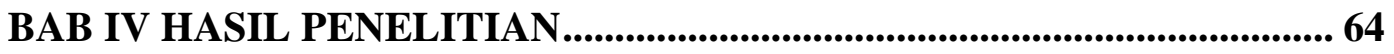

4.1 Gambaran Umum Lokasi Penelitian ............................................................. 64

4.1.1 Gambaran Umum Kelurahan 26 Ilir .............................................. 64

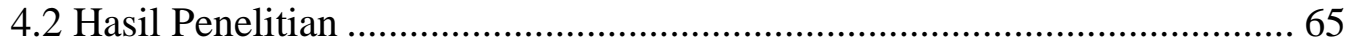

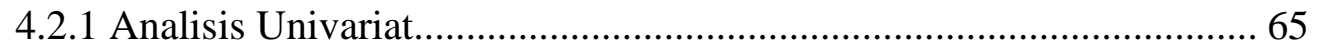

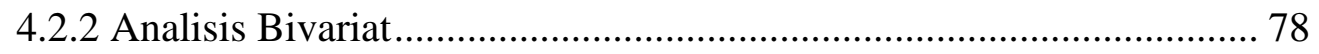

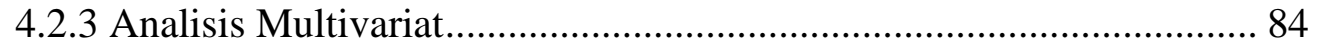

BAB V PEMBAHASAN ....................................................................... 90

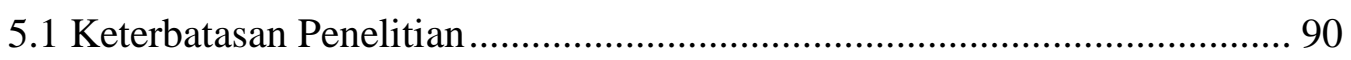

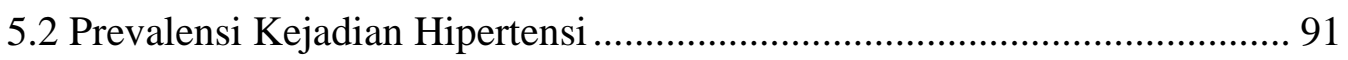

5.3 Hubungan antara Intensitas Kebisingan dengan Kejadian Hipertensi ........ 91

5.4 Hubungan antara Usia dengan Kejadian Hipertensi ................................ 94

5.5 Hubungan antara Riwayat Keluarga dengan Kejadian Hipertensi............. 96

5.6 Hubungan antara Merokok dengan Kejadian Hipertensi ........................... 98

5.7 Hubungan antara Aktivitas Fisik dengan Kejadian Hipertensi ................ 100

5.8 Hubungan antara Jarak Rumah dengan Kejadian Hipertensi................... 102

5.9 Hubungan antara Barrier dengan Kejadian Hipertensi ............................ 104

5.10 Hubungan antara Keberadaan Tanaman Hias dengan Kejadian Hipertensi 
5.11 Hubungan Variabel Confounding dengan Intensitas Kebisingan dan

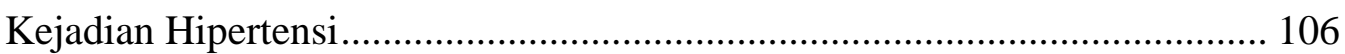

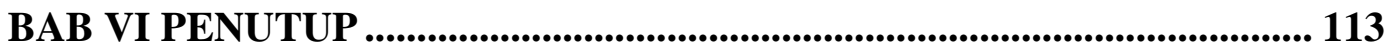

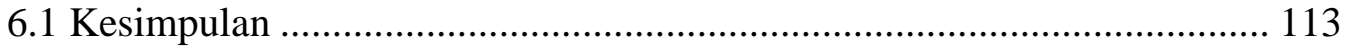

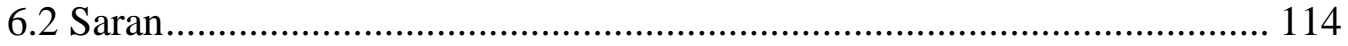

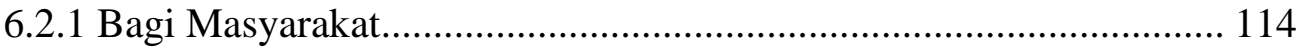

6.2.2 Bagi Kelurahan 26 Ilir Palembang ............................................... 115

6.2.3 Bagi Peneliti Selanjutnya ......................................................... 115

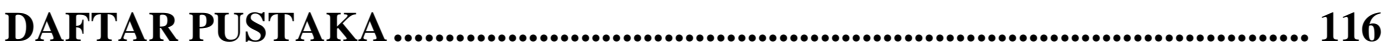

\section{LAMPIRAN}




\section{DAFTAR TABEL}

Tabel 2.1 Guidelines for community noise 13

Tabel 2.2 Baku Tingkat Kebisingan Nasional Menurut Kep-48/MENLH/11/1996 dan Peraturan Gubernur Sumatera Selatan No. 17 Tahun 2005 13

Tabel 2.3 Skala Intensitas Kebisingan dan Sumbernya .................................. 14

Tabel 2.4 Klasifikasi tekanan darah menurut WHO-ISH (1999) ....................... 22

Tabel 2.5 Klasifikasi tekanan darah menurut JNC-VII .................................... 23

Tabel 2.6 Klasifikasi tekanan darah menurut Depkes (2016) ............................. 23

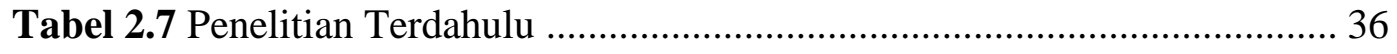

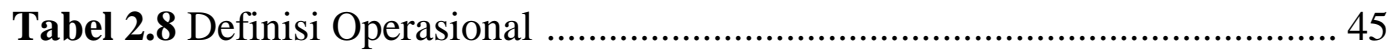

Tabel 4.1 Distribusi Frekuensi Kejadian Hipertensi ....................................... 65

Tabel 4.2 Distribusi Frekuensi Kejadian Hipertensi Berdasarkan Kelompok Usia 66

Tabel 4.3 Distribusi Statistik Intensitas Kebisingan......................................... 67

Tabel 4.4 Distribusi Frekuensi Intensitas Kebisingan ....................................... 68

Tabel 4.5 Distribusi Frekuensi Sumber Kebisingan.......................................... 69

Tabel 4.6 Distribusi Frekuensi Masa Tinggal Responden................................. 70

Tabel 4.7 Distribusi Frekuensi Usia ............................................................ 71

Tabel 4.8 Distribusi Frekuensi Usia Berdasarkan Kelompok Usia..................... 71

Tabel 4.9 Distribusi Frekuensi Riwayat Keluarga ......................................... 72

Tabel 4.10 Distribusi Frekuensi Anggota Keluarga yang Hipertensi.................. 72

Tabel 4.11 Distribusi Frekuensi Merokok...................................................... 73

Tabel 4.12 Distribusi Frekuensi Kebiasaan Merokok Berdasarkan Jenis Kelamin 73

Tabel 4.13 Distribusi Frekuensi Aktivitas Fisik ................................................ 74

Tabel 4.14 Distribusi Frekuensi Jarak Rumah ................................................. 74

Tabel 4.15 Distribusi Frekuensi Jarak Rumah Terhadap Intensitas Kebisingan .. 75

Tabel 4.16 Distribusi Frekuensi Barrier ..................................................... 75

Tabel 4.17 Distribusi Frekuensi Barrier Berdasarkan Jenisnya......................... 76

Tabel 4.18 Distribusi Frekuensi Barrier Terhadap Intensitas Kebisingan........... 76

Tabel 4.19 Distribusi Frekuensi Keberadaan Tanaman Hias .............................. 77 
Tabel 4.20 Distribusi Frekuensi Keberadaan Tanaman Hias Berdasarkan Jenisnya

Tabel 4.21 Rata-Rata Jumlah Tanaman Hias Berdasarkan Jenisnya .................. 78

Tabel 4.22 Hubungan Intensitas Kebisingan dengan Kejadian Hipertensi .......... 79

Tabel 4.23 Hubungan Usia dengan Kejadian Hipertensi .................................. 80

Tabel 4.24 Hubungan Riwayat Keluarga dengan Kejadian Hipertensi................ 80

Tabel 4.25 Hubungan Merokok dengan Kejadian Hipertensi ............................. 81

Tabel 4.26 Hubungan Aktivitas Fisik dengan Kejadian Hipertensi .................... 82

Tabel 4.27 Hubungan Jarak Rumah dengan Kejadian Hipertensi....................... 82

Tabel 4.28 Hubungan Barrier dengan Kejadian Hipertensi.............................. 83

Tabel 4.29 Hubungan Keberadaan Tanaman Hias dengan Kejadian Hipertensi . 84

Tabel 4.30 Pemodelan Awal Analisis Multivariat ........................................... 85

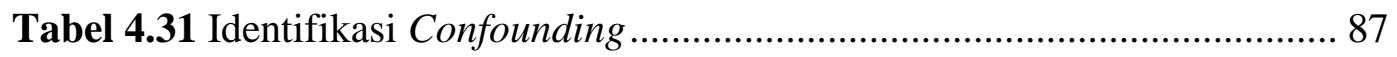

Tabel 4.32 Pemodelan Akhir Analisis Multivariat.............................................. 88 


\section{DAFTAR GAMBAR}

Gambar 2.1 Grafik distribusi sumber bising di Norway ................................ 10

Gambar 2.2 Tanaman Pereduksi Kebisingan ............................................. 17

Gambar 2.3 Skema alur mekanisme biologis kebisingan terhadap terjadinya

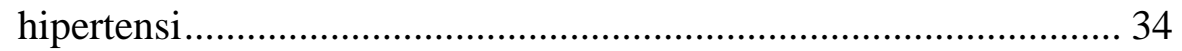

Gambar 2.4 Bagan Kerangka Teori .............................................................. 43

Gambar 2.5 Bagan Kerangka Konsep .............................................................. 44

Gambar 3.1 Skema Alur Penelitian Cross Sectional .......................................... 50

Gambar 3.2 Seleksi Subjek Penelitian........................................................... 53

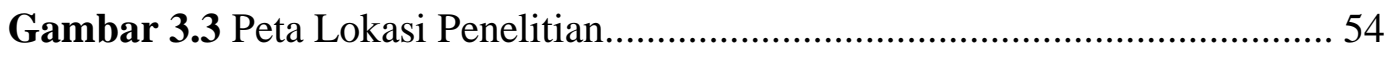

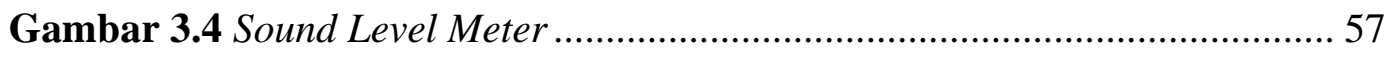

Gambar 3.5 Aneroid Sphygmomanometer .................................................... 58

Gambar 4.1 Gambar Perbatasan Wilayah Kelurahan 26 Ilir .............................. 64

Gambar 4.2 Gambar Titik Pengukuran di Lokasi Penelitian ............................ 67 


\section{BAB I \\ PENDAHULUAN}

\subsection{Latar Belakang}

Populasi di seluruh dunia kian bertambah seiring bertambahnya waktu. Ketika terjadinya pertumbuhan populasi melewati kapasitas tampung atau muat pada suatu wilayah maka akan berakhir dengan kelebihan penduduk atau biasa yang dikenal dengan kepadatan penduduk (Hardianti dan Umar, 2015). Dengan data jumlah populasi dunia terakhir per April 2020 menurut United Nations (PBB) yang dikutip oleh Worldometer adalah 7,8 miliar jiwa. Data menurut kutipan Worldometer menunjukkan bahwa jumlah penduduk di dunia pada tahun 2019 telah meningkat sebesar 1,08\% dari 2018 lalu. Berdasarkan data yang dirangkum oleh Worldometer, Asia masih menduduki sebagai benua yang memiliki populasi terbanyak diantara benua-benua yang lain dengan total populasi sebesar 4,6 miliar jiwa per tanggal 20 April 2020 menurut United States (PBB). Di antara 51 negara yang ada di Asia, Indonesia menempati posisi ke-3 sebagai negara yang mempunyai jumlah populasi terbanyak di Asia yaitu sebesar 273 juta jiwa.

Salah satu akibat pertumbuhan penduduk yaitu akan terus menyebabkan tingkat polusi yang dihasilkan ke lingkungan. Menurut Abdi dan Rahma (2018), polusi tidak hanya terjadi pada udara, tanah, maupun air, polusi dalam bentuk suara juga termasuk sebagai polusi yang berupa kebisingan di daerah perkotaan (Abdi dan Rahma, 2018). Kebisingan sendiri termasuk gelombang bunyi atau suara yang tidak dikehendaki dan dapat mengganggu kesehatan dan kenyamanan lingkungan. Dalam Keputusan Menteri Lingkungan Hidup Nomor 48 Tahun 1996 menyebutkan bahwa kebisingan adalah bunyi yang tidak diinginkan dari usaha atau kegiatan dalam tingkat dan waktu tertentu yang dapat menimbulkan gangguan kesehatan masyarakat dan kenyamanan lingkungan.

Kebisingan adalah salah satu jenis pencemaran udara yang masih dianggap tidak begitu berdampak secara langsung terhadap manusia terutama pada masyarakat yang tinggal di pemukiman atau yang tinggal sekitar bahkan dekat dengan jalan raya (yang menjadi sala satu sumber kebisingan) sehingga kebisingan di lingkungan masih kerap diabaikan dampak kesehatannya. Hasil penelitian Suroto 
(2010) mengemukakan bahwa saat sekarang ini sumber kebisingan yang dominan didapatkan dari kebisingan lalu lintas (Suroto, 2010). Namun nilai nominal intensitas kebisingan yang diterima masyarakat akan terdapat perubahan dari nilai kebisingan yang dikeluarkan dikarenakan beberapa faktor lain seperti jarak rumah warga dari sumber kebisingan dan menurut penelitian yang dilakukan oleh Kurnia (2018) terdapatnya barrier (pohon, pagar, dan gedung atau bangunan) juga dapat mereduksi intensitas kebisingan yang akan diterima, juga jenis tanaman (seperti Tanjung, Kembang Sepatu, Imodia, Pucuk Merah, Walisongo, dan Soka) ikut menyertai sebagai faktor yang mempengaruhi intensitas kebisingan yang akan diterima masyarakat (Kurnia et al., 2018).

Pada sebuah penelitian menyebutkan bahwa jarak rumah pemukiman yang berada 11-20 meter dari jalan raya memiliki korelasi dengan tingkat ketergangguan masyarakat (Alsey et al., 2017). Terdapat pula data yang didapat dari penelitian Martono (2004), kebisingan yang didapat dari pengukuran berjarak $80 \mathrm{~m}$ dari jalan raya bahkan masih tetap melampaui standar yang diberlakukan dengan kebisingan tertinggi di Jakarta Barat sebesar 69,64 dB dan terendah di Tangerang sebesar 63,59 dB yang mengartikan bahwa jarak antara bangunan dengan jalan raya akan berpengaruh terhadap intensitas kebisingan yang akan diterima (Martono, 2004).

Laporan data dari World Health Organization (WHO) dalam Departemen Kesehatan RI (1995) menyatakan bahwa 8-12\% penduduk dunia telah menderita dampak kebisingan dalam berbagai bentuk dan diperkirakan akan terus meningkat, dan pada tahun 2001 diperkirakan 120 juta penduduk dunia mengalami gangguan pendengaran. World Health Organization (WHO) juga mengemukakan bahwa kebisingan dalam kota merupakan jenis polusi paling berbahaya setelah polusi udara dan air karena kebisingan dapat menyebabkan berbagai gangguan seperti gangguan fisiologis, psikologis, dan komunikasi (Abdi dan Rahma, 2018).

Dampak kebisingan terhadap kesehatan bisa berupa gangguan pada indera pendengaran dan non indera pendengaran (Suma'mur, 2009). Pada indera pendengaran, bising dapat merusak telinga bagian tengah dan bagian dalam. Kehilangan kemampuan pada indera pendengaran yang diakibatkan oleh terpaparnya seseorang dengan kebisingan yang umumnya akan merusak sel-sel rambut pada telinga bagian dalam yang lalu merusak sel-sel syaraf pendengaran. 
Kerusakan sel-sel syaraf pendengaran dapat juga menyebabkan dampak non indera pendengaran seperti gangguan fisiologis berupa peningkatan tekanan darah, peningkatan nadi, kontruksi pembuluh darah parifer terutama pada tangan dan kaki, serta gangguan psikologis berupa rasa tidak nyaman, kurang konsentrasi, susah tidur, cepat marah dan stres kerja (Kristiyanto et al., 2014).

Menurut data yang disajikan oleh World Health Organization (WHO), (2013) di seluruh dunia, ada sekitar satu miliar jiwa yang mengidap hipertensi, angka ini memungkinkan untuk terjadi peningkatan menjadi sebesar 1,5 miliar jiwa di tahun 2025 (WHO, 2013). Dari 972 juta jiwa yang mengalami hipertensi, 333 juta jiwa berada di negara maju dan 639 juta sisanya berada di negara berkembang, termasuk Indonesia (Yonata dan Pratama, 2016). Menurut hasil RISKESDAS (2007), prevalensi hipertensi di Indonesia sangat tinggi dengan persentase 31,7\% jika dibandingkan dengan negara tetangga yang memiliki persentase 27,3\% (Singapura), 22\% (Thailand), dan 20\% (Malaysia) (AS, 2010). Prevalensi hipertensi di Indonesia dari tahun 2013 yang mempunyai persentase sebesar 25,8\% ke tahun 2018 yang persentasenya meningkat menjadi 34,1\% (Kementerian Kesehatan RI, 2018). Prevalensi kejadian hipertensi menurut data Dinas Kesehatan Provinsi Sumatera Selatan (2019), jumlah penderita hipertensi di Sumaera Selatan terjadi sebanyak 5,5 juta jiwa dengan penyumbang angka tertinggi terjadi pada kota palembang sebesar 1,1 juta jiwa (20,2\%) dan 35\% untuk wilayah bagian kecamatan Bukit Kecil, Palembang (Dinas Kesehatan Kota Palembang, 2017).

WHO (1996) mengemukakan bahwa faktor lingkungan seperti polusi suara atau kebisingan merupakan faktor risiko hipertensi. Kebisingan bukanlah merupakan satu-satunya faktor pemicu terjadinya hipertensi. Pernyataan tersebut didukung dengan pernyataan Chobanian (2003) yang dimana adanya faktor-faktor risiko lain hipertensi yaitu usia, jenis kelamin, kurangnya gaya hidup sehat yang meliputi aktivitas fisik, merokok, konsumsi alkohol, konsumsi kopi, juga riwayat hipertensi (Chobanian et al., 2003).

Beberapa hasil penelitian menyatakan bahwa hipertensi akibat kebisingan terdapat hubungan dan berisiko lebih besar terkena pada masyarakat yang terpapar kebisingan dalam jangka waktu yang cukup lama dan secara kontinyu ( $\mathrm{p}=0,001$ ( $\mathrm{p}$ 
$<$ 0,05) (Palupi dan Sari, 2018); OR: 1,22 dengan intensitas > 55 dB (Bodin et al., 2009); OR: 1,21 dengan intensitas > $64 \mathrm{~dB}$ (Kluizenaar et al., 2011)).

Salah satunya di Kelurahan 26 Ilir di Kecamatan Bukit Kecil, Kota Palembang. Jalan tersebut selalu padat di jam-jam tertentu dan merupakan daerah yang padat penduduk sehingga akan mengakibatkan kemacetan dan menghasilkan kebisingan. Hal tersebut dikarenakan di salah satu sisi seperti pada Jalan Radial yang menjadi jalan masuk dari dua jalan lain yaitu Jalan POM IX dan Jalan Kapten A. Rivai dan dihadapi dengan tiga pemberhentian lampu lalu lintas dari tiga persimpangan. Kemudian pada sisi lainnya yaitu jalan Brigjen HM. Dhani Effendi yang di ujung perbatasan jalannya berdekatan dengan pasar tradisional yang ikut menyumbangkan kemacetan lalu lintas. Sehingga masyarakat yang bermukim di sepanjang dan sekitar jalan tersebut juga akan ikut merasakan dampaknya. Hal ini sejalan dengan penelitian (Alsey et al., 2017) mengenai pencemaran lingkungan kebisingan akibat lalu lintas di jalan raya sekitar pemukiman Sungai Raya Kecamatan Pontianak Tenggara, bahwa pemukiman yang berjarak 11-20 meter dari jalan memperlihatkan hasil adanya nilai hubungan antara kebisingan dengan ketergangguan yang diterima masyarakat.

Apabila ditinjau dari UU Kesehatan No. 36 Tahun 2009 mengenai kesehatan lingkungan, setiap manusia mengupayakan kesehatan lingkungan yang salah satunya, lingkungan pemukiman yang bebas dari unsur-unsur yang menimbulkan gangguan kesehatan antara lain kebisingan yang melebihi ambang batas ditujukan untuk mewujudkan kualitas ingkungan yang sehat secara fisik, kimia, biologi, maupun sosial yang memungkinkan setiap orang mencapai derajat kesehatan yang setinggi-tingginya. Sehingga untuk mengetahui lebih jauh mengenai hubungan kebisingan dengan hipertensi pada masyarakat yang bermukim di Kelurahan 26 Ilir, Bukit Kecil Kota Palembang, maka penulis melakukan penelitian ini.

\subsection{Rumusan Masalah}

Tingkat kebisingan merupakan faktor pencemar udara yang dalam intensitas tertentu dapat menimbulkan gangguan kesehatan. Peningkatan tekanan darah merupakan gejala awal yang dapat di deteksi sebagai akibat dari pengaruh 
kebisingan. Oleh karena itu rumusan masalah dari penelitian ini adalah "adakah hubungan antara intensitas kebisingan dengan kejadian hipertensi pada masyarakat di pemukiman kelurahan 26 Ilir Kecamatan Bukit Kecil Kota Palembang?"

\subsection{Tujuan}

\subsubsection{Tujuan Umum}

Tujuan umum dari penelitian ini adalah untuk mengetahui hubungan antara intensitas kebisingan dengan kejadian hipertensi pada masyarakat di pemukiman kelurahan 26 Ilir Kecamatan Bukit Kecil Kota Palembang.

\subsubsection{Tujuan Khusus}

Adapun tujuan khusus dari penelitian ini adalah:

1. Menganalisis prevalensi hipertensi di Kecamatan Bukit Kecil Kota Palembang.

2. Menganalisis distribusi frekuensi intensitas kebisingan dalam rumah masyarakat di pemukiman Kelurahan 26 Ilir Bukit Kecil Kota Palembang.

3. Menganalisis distribusi frekuensi variabel lain yang ikut diteliti seperti usia, riwayat keluarga, merokok, aktivitas fisik, jarak rumah, barrier, dan keberadaan tanaman hias.

4. Menganalisis hubungan antara intensitas kebisingan dengan hipertensi pada masyarakat yang tinggal di Kelurahan 26 Ilir Bukit Kecil Kota Palembang.

5. Menganalisis hubungan usia terhadap kejadian hipertensi pada masyarakat yang tinggal di Kelurahan 26 Ilir Bukit Kecil Kota Palembang.

6. Menganalisis hubungan riwayat keluarga terhadap kejadian hipertensi pada masyarakat yang tinggal di Kelurahan 26 Ilir Bukit Kecil Kota Palembang.

7. Menganalisis hubungan merokok terhadap kejadian hipertensi pada masyarakat yang tinggal di Kelurahan 26 Ilir Bukit Kecil Kota Palembang. 
8. Menganalisis hubungan aktivitas fisik terhadap kejadian hipertensi pada masyarakat yang tinggal di Kelurahan 26 Ilir Bukit Kecil Kota Palembang.

9. Menganalisis hubungan jarak rumah terhadap kejadian hipertensi pada masyarakat yang tinggal di Kelurahan 26 Ilir Bukit Kecil Kota Palembang.

10. Menganalisis hubungan barrier terhadap kejadian hipertensi pada masyarakat yang tinggal di Kelurahan 26 Ilir Bukit Kecil Kota Palembang.

11. Menganalisis hubungan keberadaan tanaman hias terhadap kejadian hipertensi pada masyarakat yang tinggal di Kelurahan 26 Ilir Bukit Kecil Kota Palembang.

12. Menganalisis nilai risiko adjusted dari intensitas kebisingan terhadap kejadian hipertensi pada masyarakat tinggal di Kelurahan 26 Ilir Bukit Kecil Kota Palembang setelah dikontrol dengan faktor-faktor atau variabel lainnya.

\subsection{Manfaat Penelitian}

\subsubsection{Bagi Peneliti}

Penelitian ini dapat sebagai sarana untuk memberikan gambaran serta menambah wawasan peneliti mengenai hubungan intensitas kebisingan terhadap kejadian hipertensi pada masyarakat yang tinggal di Kelurahan 26 Ilir Bukit Kecil Kota Palembang. Serta menjadi referensi bagi peneliti selanjutnya mengenai intensitas kebisingan terhadap kejadian hipertensi pada masyarakat.

\subsubsection{Bagi Fakultas Kesehatan Masyarakat}

Dapat digunakan sebagai informasi kepada civitas akademika tentang hubungan intensitas kebisingan terhadap kejadian hipertensi pada masyarakat sehingga mampu menambah wawasan bagi Mahasiswa Fakultas Kesehatan Masyarakat Universitas Sriwijaya.

\subsubsection{Bagi Masyarakat}

Penelitian ini diharapkan mampu meningkatkan pemahaman masyarakat mengenai dampak kesehatan yang ditimbulkan akibat paparan kebisingan terhadap 
hipertensi pada masyarakat agar kedepannya dapat mengurangi dan mencegah paparan tersebut.

\subsubsection{Bagi Pemerintah}

Memberikan rekomendasi, gambaran, dan masukan alternatif kebijakan pemerintah untuk mengurangi tingkat kebisingan di kawasan tempat tinggal masyarakat yang ada di Kelurahan 26 Ilir, Bukit Kecil, Kota Palembang.

\subsection{Ruang Lingkup Penelitian}

\subsubsection{Lingkup Materi}

Lingkup materi penelitian ini membahas tentang hubungan intensitas kebisingan dengan kejadian hipertensi dengan faktor yang mempengaruhi intensitas kebisingan dan faktor yang ikut mempengaruhi kejadian hipertensi.

\subsubsection{Lingkup Lokasi}

Penelitian ini akan dilakukan di pemukiman warga yang ada di Kelurahan 26 Ilir, Bukit Kecil, Kota Palembang.

\subsubsection{Lingkup Waktu}

Penelitian ini akan dilaksanakan pada bulan Oktober-Desember 2020. 


\section{DAFTAR PUSTAKA}

Abdi, A. W. \& Rahma, F. 2018. Tingkat Kebisingan Suara Transportasi Di Kota Banda Aceh. Gea. Jurnal Pendidikan Geografi, 18, 11.

Alsey, F. A., et al. 2017. Analisis Tingkat Kebisingan Akibat Arus Lalu Lintas Di Pemukiman Kota Pontianak (Studi Kasus : Pemukiman Sungai Raya Dalam Kecamatan Pontianak Tenggara). Jurnal Teknologi Lingkungan Lahan Basah, 5.

Aluko, E. O. \& Nna, V. U. 2015. Impact of Noise Pollution on Human Cardiovascular System. International Journal of Tropical Disease \& Health, 6, 35-43.

Afif, M. 2018. Perbedaan Hasil Pengukuran Tekanan Darah Pada Lengan Dan Kaki Pasien Di RS Roemani Muhammadiyah Semarang. Skripsi. Program Studi S1 Keperawatan Universitas Muhammadiyah Semarang. Semarang.

Aly, S. H., et al. 2014. Analisis Tingkat Pengurangan Kebisingan Oleh Tanaman Di Ruas Jl. Ap. Pettarani Di Kota Makassar Analyze of Noise Reduction by Plant in Ap. Pettarani Roadway in City of Makassar.

Andrea, G. Y. 2013. Korelasi Derajat Hipertensi Dengan Stadium Penyakit Ginjal Kronik Di RSUP Dr. Kariadi Semarang Periode 2008-2012. Skripsi. Fakultas Kedokteran Universitas Diponegoro Semarang. Semarang.

Anggara, F. H. D., Prayitno, Nanang 2013. Faktor-Faktor Yang Berhubungan Dengan Tekanan Darah Di Puskesmas Telaga Murni, Cikarang Barat Tahun 2012. Jurnal ilmiah kesehatan, 5, 20-25.

Anggraeni, V. 2012. Tingkat Kebisingan Lalu Lintas Dan Risiko Hipertensi Pada Supir Angkutan Umum KWK Wilayah Jakarta Timur Tahun 2012. Skripsi. Fakultas Kesehatan Masyarakat Universitas Indonesia. Depok.

Anwari, M., et al. 2018. Pemberian Senam Antihipertensi Sebagai Upaya Menstabilkan Tekanan Darah: Studi Kasus Pada Keluarga Binaan Di Desa Kemuningsari Lor Kecamatan Panti Kabupaten Jember. The Indonesian Journal of Health Science, 165-168.

Ardian, I. 2018. Signifikansi Tingkat Stres Dengan Tekanan Darah Pada Pasien Hipertensi. Unissula Nursing Conference Call for Paper \& National Conference, 2018. 152-156.

Ardiansyah, M. 2012. Medikal Bedah Untuk Mahasiswa. Jogjakarta: Diva Perss. 
Arif, D., et al. 2013. Faktor-Faktor Yang Berhubungan Dengan Kejadian Hipertensi Pada Lansia Di Pusling Desa Klumpit Upt Puskesmas Gribig Kabupaten Kudus. Jurnal Ilmu Keperawatan dan Kebidanan, 4.

Artiyaningrum, B. 2015. Faktor-Faktor Yang Berhubungan Dengan Kejadian Hipertensi Tidak Terkendali Pada Penderita Yang Melakukan Pemeriksaan Rutin Di Puskesmas Kedungmundu Kota Semarang Tahun 2014. Skripsi. Fakultas Kesehatan Masyarakat Univesitas Negeri Semarang. Semarang.

AS, M. 2010. Hidup Bersama Hipertensi Seringai Darah Tinggi Sang Pembunuh Sekejap, Yogyakarta, In-Noobs.

Asfian, P. 2017. Faktor-Faktor Yang Berhubungan Dengan Gangguan Psikologis Akibat Kebisingan Pada Teknisi Di Perseroan Terbatas Perusahaan Listrik Negara Sektor Pembangkit Kendari Unit Poasia Tahun 2016. (Jurnal Ilmiah Mahasiswa Kesehatan Masyarakat), 1.

Asfaw, L. S., et al. 2018. Hypertension and Its Associated Factors in Hosanna Town, Southern Ethiopia: Community Based Cross-Sectional Study. BMC research notes, 11, 1-6.

Ayu, M. 2019. Hubungan Intensitas Kebisingan Pelabuhan Boom Baru Palembang Dengan Risiko Hipertensi Pada Wanita Yang Tinggal Di Wilayah Sabokingking Tahun 2019. Skripsi, Universitas Sriwijaya.

Babba, J. 2007. Hubungan Antara Intensitas Kebisingan Di Lingkungan Kerja Dengan Peningkatan Tekanan Darah (Penelitian Pada Karyawan Pt Semen Tonasa Di Kabupaten Pangkep Sulawesi Selatan)(Relationship between Noise Intensity in Working Environment and the Hipertension (Study on Pt. Semen Tonasa Worker in Pangkep District Sount Sulawesi). Program Pascasarjana Universitas Diponegoro.

Babisch, W., et al. 2013. Noise Annoyance-a Modifier of the Association between Noise Level and Cardiovascular Health? Science of the total environment, 452, 50-57.

Basner, M., et al. 2014. Auditory and Non-Auditory Effects of Noise on Health. The lancet, 383, 1325-1332.

Bodin, T., et al. 2009. Road Traffic Noise and Hypertension: Results from a CrossSectional Public Health Survey in Southern Sweden. Environmental Health, 8,38 .

Buchari 2007. Kebisingan Industri Dan Hearing Conservation Program, Repository USU. 
Buntaa, J. N., et al. 2018. Faktor-Faktor Risiko Kejadian Hipertensi Nelayan Di Desa Mala Dan Mala Timur Kecamatan Melonguane Kabupaten Kepulauan Talaud. KESMAS, 7.

Buss, J. \& Labus, D. 2013. Buku Saku Patofisiologi Menjadi Sangat Mudah Edisi 2. Diterjemahkan oleh Huriawati Hartanto. Jakarta: EGC.

Cahyani, A. A. 2019. Pengaruh Kebisingan Lingkungan Kerja Terhadap Produktivitas Kinerja Karyawan Dinas Kesehatan Kabupaten Sidoarjo. Tesis. Fakultas Kesehatan Masyarakat Universitas Muhammadiyah Gresik. Gresik.

CDC. Dari: https://www.cdc.gov/nchs/nhis/tobacco/tobacco_glossary.htm [Diakses 11 Juni 2020].

Chandra, B. 2007. Pengantar Kesehatan Lingkungan, Jakarta, Jakarta EGC.

Chandra, W. 2014. Hubungan Antara Pola Makan Vegetarian Dengan Prevalensi Hipertensi Pada Komunitas Vihara Periode Juni 2014. Universitas Tarumanegara.

Chobanian, A. V., et al. 2003. The Seventh Report of the Joint National Committee on Prevention, Detection, Evaluation, and Treatment of High Blood Pressure: The Jnc 7 Report. Jama, 289, 2560-2571.

Dalimartha, S., et al. 2008. Care Your Self, Hipertensi, Penebar PLUS+.

Darlani, D. \& Sugiharto, S. 2017. Kebisingan Dan Gangguan Psikologis Pekerja Weaving Loom Dan Inspection Pt. Primatexco Indonesia. Journal of Health Education, 2, 130-137.

Departemen Kesehatan RI. 2007. Pedoman Surveilans Epidemiologi Penyakit Jantung dan Pembuluh Darah. Jakarta. Departemen Kesehatan RI.

Departemen Kesehatan RI. 2006. Pedoman Teknis Penemuan dan Penatalaksanaan Penyakit Hipertensi. Jakarta. Direktorat Pengendalian Penyakit Tidak Menular.

Departemen Kesehatan RI 1995. Petunjuk Pelaksanaan Pengawasan Kebisingan, Jakarta, Departemen Kesehatan RI.

Dinas Kesehatan Kota Palembang 2017. Data Dasar Kesehatan Kota Palembang Tahun 2017, Palembang, Dinas Kesehatan Kota Palembang.

Dinas Kesehatan Kota Palembang 2013. Data Dasar Kesehatan Kota Palembang Tahun 2013, Palembang, Dinas Kesehatan Kota Palembang. 
Dinas Kesehatan Provinsi Sumatera Selatan 2019. Profil Kesehatan Provinsi Sumatera Selatan Tahun 2019, Palembang, Dinas Kesehatan Provinsi Sumatera Selatan.

Djalante, S. 2010. Analisis Tingkat Kebisingan Di Jalan Raya Yang Menggunakan Alat Pemberi Isyarat Lalu Lintas (Apil) (Studi Kasus: Simpang Ade Swalayan). SMARTek, 8.

Dzulfiqar, F. \& Budiono, Z. 2015. Hubungan Intensitas Suara Dengan Tekanan Darah Pada Pekerja Pt. Tradha Asphalt Mixing Plant (Amp) Kecamatan Pejagoan Kabupaten Kebumen Tahun 2015. Buletin Keslingmas, 34, 290295.

Elvivin, E., et al. 2017. Analisis Faktor Risiko Kebiasaan Mengkonsumsi Garam, Alkohol, Kebiasaan Merokok Dan Minum Kopi Terhadap Kejadian Dipertensi Pada Nelayan Suku Bajo Di Pulau Tasipi Kabupaten Muna Barat Tahun 2015. (Jurnal Ilmiah Mahasiswa Kesehatan Masyarakat), 1.

Emmerich, E., et al. 2008. Is the Audiologic Status of Professional Musicians a Reflection of the Noise Exposure in Classical Orchestral Music? European Archives of Oto-Rhino-Laryngology, 265, 753-758.

Farcas, F. 2008. Road Traffic Noise, a Study of Skane Region Sweden. Master's thesis, Lincoping University.

Ferri, F. F. 2017. Ferri's Clinical Advisor 2018 E-Book: 5 Books in 1, Elsevier Health Sciences.

Fitriayani, Y., et al. 2020. Faktor Yang Berhubungan Dengan Kejadian Hipertensi Esensial Di Desa Kemingking Dalam Kabupaten Muaro Jambi. Journal Of Healthcare Technology And Medicine, 6, 449-458.

Gubernur Sumatera Selatan. 2005. Peraturan Gubernur Sumatera Selatan Nomor 17 Tahun 2005 Tentang: Baku Mutu Udara Ambien dan Baku Tingkat Kebisingan. Palembang. Gubernur Sumatera Selatan.

Gunawan 2007. Hipertensi, Jakarta, PT Gramedia.

Gunawan, L. 2001. Hipertensi, Yogyakarta, Kanisius.

Hamdi, S. 2018. Terapi Gelombang Kejut Sebuah Terobosan Di Bidang Fisika Medik. Media Dirgantara, 13.

Hardianti, H. \& Umar, A. 2015. Kinerja Bkkbn Provinsi Sulawesi Selatan Dalam Menekan Angka Pertumbuhan Penduduk Di Kota Makassar. Pena: Jurnal Kreativitas Ilmiah Mahasiswa Unismuh, 2, 308-318. 
Hasanah, U., et al. 2016. Tingkat Kebisingan Di Kawasan Permukiman Sekitar Pltd Muara Teweh. JURNAL KESEHATAN LINGKUNGAN: Jurnal dan Aplikasi Teknik Kesehatan Lingkungan, 13, 328-336.

Hasmah, H., et al. 2021. Faktor Yang Hubungan Dengan Kejadian Hipertensi Di Rsud Kolonodale Kabupaten Morowali Utara. (Jurnal Ilmiah Mahasiswa Kesehatan Masyarakat), 6.

Hastuti, E. 2005. Faktor-Faktor Risiko Kenaikan Tekanan Darah Pada Pekerja Yang Terpajan Kebisingan di Bandara Ahmad Yani Semarang. Tesis. Universitas Diponegoro. Semarang.

Hastono, S. P. 2016. Analisis Data Pada Bidang Kesehatan, Jakarta, RajaGrafindo Persada.

Herawati, C. \& Yuslichah, A. 2018. Analisis Faktor Risiko Kejadian Hipertensi Pada Pekerja Pelabuhan. Jurnal Kesehatan, 9, 1162-1166.

Hernayati, M. A., et al. 2018. Hubungan Kebisingan Di Bandara Halim Perdanakusuma Jakarta Timur Terhadap Gangguan Non-Auditori Permukiman Penduduk Wilayah Buffer. Jurnal Kesehatan Masyarakat (eJournal), 6, 214-224.

Hidayat, I. W. 2008. Evaluasi Jalur Hijau Jalan Sebagai Penyangga Lingkungan Sekitarnya Dan Keselamatan Pengguna Jalan Bebas Hambatan Jagorawi. Tesis. Institut Pertanian Bogor. Bogor.

Ikron, I. \& Wulandari, R. A. 2007. Pengaruh Kebisingan Lalulintas Jalan Terhadap Gangguan Kesehatan Psikologis Anak Sdn Cipinang Muara Kecamatan Jatinegara, Kota Jakarta Timur, Propinsi Dki Jakarta, 2005. Majalah Kesehatan, 11, 32-7.

Ip, S. 2012. Penyakit Degeneratif: Mengenal, Mencegah, Dan Mengurangi Faktor Resiko 9 Penyakit Degeneratif, Jakarta, Nuha Medic.

Irianto, K. 2014. Ilmu Kesehatan Masyarakat. Bandung: Alfabeta.

Jaya, M. 2009. Pembunuh Berbahaya Itu Bernama Rokok, Yogyakarta, Riz'ma.

Kalangi, J. A., et al. 2015. Hubungan Faktor Genetik Dengan Tekanan Darah Pada Remaja. e-CliniC, 3.

Kalantary, S., et al. 2015. The Effects of Occupational Noise on Blood Pressure and Heart Rate of Workers in an Automotive Parts Industry. ARYA atherosclerosis, 11, 215.

Kamila, M. 2017. Efektifitas Latihan Slow Deep Breathing dan Pemberian Aromaterapi (Cananga odorata) Terhadap Penurunan Tekanan Darah 
Pada Penderita Hipertensi di Puskesmas Karangdoro. Skripsi. Program Studi S1 Keperawatan Universitas Muhammadiyah Semarang. Semarang.

Kartikawati. A. 2008. Prevalensi dan Determinan Hipertensi Pada Pasien Puskesmas di Jakarta Utara Tahun 2007. Skripsi. Fakultas Kesehatan Masyarakat Universitas Indonesia. Depok.

Kellerman, R. D. \& Bope, E. T. 2017. Conn's Current Therapy 2018 E-Book, Elsevier Health Sciences.

Kementerian Kesehatan RI. 2018. Hasil Utama Riskesdas 2018, Jakarta, Badan Penelitian dan Pengembangan Kesehatan, Kementrian Kesehatan Republik Indonesia.

Kluizenaar, Y. d., et al. 2011. Urban Road Traffic Noise and Annoyance: The Effect of a Quiet Façade. The Journal of the Acoustical Society of America, 130, 1936-1942.

Kristiyanto, F., et al. 2014. Hubungan Intensitas Kebisingan Dengan Gangguan Psikologis Pekerja Departemen Laundry Bagian Washing Pt. X Semarang. Jurnal Kesehatan Masyarakat (e-Journal), 2, 75-79.

Kurnia, M., et al. 2018. Tingkat Kebisingan Yang Dihasilkan Dari Aktivitas Transportasi (Studi Kasus Pada Sebagian Ruas Jalan: Manek Roo, Sisingamangaraja Dan Gajah Mada Meulaboh). Jurnal Arsip Rekayasa Sipil dan Perencanaan (Journal of Archive in Civil Engineering and Planning), $1,1-9$.

Kurniadi, H. \& Nurrahmani, U. 2014. Stop Diabetes Hipertensi Kolesterol Tinggi Jantung Koroner, Yogyakarta, Istana Media.

Laad, M. 2011. The Study of the Effect of Sounds of Constant Frequency and Varying Intensity Levels on Systolic Blood Pressure, Diastolic Blood Pressure and Heart Rate of Healthy Individuals. Annals of the Faculty of Engineering Hunedoara, 9, 107.

Laksono, A. D., et al. 2020. Pengaruh Fraksi Volume Komposit Polyester Berpenguat Limbah Serbuk Kayu Bangkirai Terhadap Sifat Material Akustik. Rekayasa Mesin, 10, 277-285.

Lemeshow, S., et al. 1997. Besar Sampel Dalam Penelitian Kesehatan. Yogyakarta: Gajah Mada University.

Lewis, S. L., et al. 2015. Medical-Surgical Nursing-E-Book: Assessment and Management of Clinical Problems, Single Volume, Elsevier Health Sciences. 
Listyaningrum, A. W. 2011. Pengaruh Intensitas Kebisingan Terhadap Ambang Dengar Pada Tenaga Kerja di PT Sekar Bengawan Kabupaten Karanganyar. Skripsi. Fakultas Kedokteran Universitas Sebelas Maret. Surakarta.

Liu, J., et al. 2016. Prevalence of Hypertension and Noise-Induced Hearing Loss in Chinese Coal Miners. Journal of thoracic disease, 8, 422.

Martono, H. 2004. Tingkat Kebisingan Di Dki Jakarta Dan Sekitarnya.

Maulitanisa, H., et al. 2019. Faktor-Faktor Yang Berhubungan Dengan Kejadian Hipertensi Pada Masyarakat Rw 009 Kelurahan Bojong Menteng Bekasi 2018. ARKESMAS (Arsip Kesehatan Masyarakat), 4, 143-148.

Mediastika, C. E. 2005. Potensi Jendela Dalam Meminimalkan Intrusi Kebisingan: Sebuah Studi Awal. DIMENSI (Journal of Architecture and Built Environment), 33.

Medika, B. 2017. Berdamai Dengan Hipertensi, Jakarta, Bumi Medika.

Menteri Negara Lingkungan Hidup 1996. Keputusan Menteri Negara Lingkungan Hidup No. 48 Tahun 1996 Tentang: Baku Tingkat Kebisingan, Jakarta, Menteri Negara Lingkungan Hidup.

Muharissa, R. 2013. Pengaruh Penambahan Serat Jerami Padi Sebagai Peredam Suara Dan Pengaruhnya Terhadap Sifat Mekanik Beton. Skripsi. Departemen Teknik Sipil Universitas Sumatera Utara. Medan.

Munandar, A. \& Kusnoputranto, H. 2014. Pengaruh Pajanan Kebisingan Dari Perlintasan Kereta Api Terhadap Perubahan Tekanan Darah Pada Masyarakat Yang Tinggal Di Lingkungan Sekitar Stasiun Kereta Api Lemahabang, Desa Simpang, Kec. Cikarang Utara, Kab. Bekasi Tahun 2014. Depok, Universitas Indonesia.

Muninjaya, A. A. G. 2003. Langkah-Langkah Praktis Penyusunan Proposal Dan Publikasi Ilmiah, Jakarta, Penerbut Buku Kedokteran EGC.

Münzel, T., et al. 2014. Cardiovascular Effects of Environmental Noise Exposure. European heart journal, 35, 829-836.

Nasution, N. H. 2017. Hubungan Paparan Kebisingan Dan Karakteristik Pengemudi Becak Vespa Terhadap Tekanan Darah Di Kota Padangsidimpuan Tahun 2014. Jurnal Kesehatan Ilmiah Indonesia (Indonesian Health Scientific Journal), 2, 68-73.

Noviyanti, F., et al. 2015. Perbedaan Kadar Ldl-Kolesterol Pada Pasien Diabetes Melitus Tipe 2 Dengan Dan Tanpa Hipertensi Di Rs Dr. M. Djamil Padang Tahun 2011. Jurnal Kesehatan Andalas, 4. 
Nugraheni, A. T. \& Wijayanti, A. C. 2019. Faktor-Faktor Yang Berhubungan Dengan Kejadian Hipertensi Pada Perempuan Dewasa Muda Di Kabupaten Sukoharjo Tahun 2017. Proceeding of The URECOL, 46-51.

Nuraini, B. 2015. Risk Factors of Hypertension. Jurnal Majority, 4.

Nurfitriyana, N., et al. 2020. Influencing Factors of Hearing Disorder in Helicopter and Casa Pilots. Journal of Medicine and Health, 2.

Nurjanah, D. R., et al. 2019. Hubungan Pajanan Kebisingan Dengan Tekanan Darah Pada Pekerja Pt. Iskandar Indah Printing Textile Surakarta. MEDIA KESEHATAN MASYARAKAT INDONESIA, 19, 147-151.

Nurwijayanti, A. M., et al. 2019. Perbedaan Hasil Pengukuran Tekanan Darah Posisi Berbaring Dan Berdiri Pada Penderita Hipertensi. Jurnal Keperawatan, 11, 27-32.

Oktari, I. S. 2019. Hubungan Intensias Kebisingan di Ruang Mesin Dengan Kejadian Hipertensi pada Anak Buah Kapal di Pelabuhan Pulai Baai Bengkulu. Skripsi. Fakultas Kesehatan Masyarakat Universitas Diponegoro. Semarang.

Padila, S. \& Kep, N. 2013. Asuhan Keperawatan Penyakit Dalam. Nuha Medika, Yogyakarta.

Palupi, E. W. \& Sari, A. N. 2018. Faktor-Faktor Yang Berhubungan Dengan Kejadian Hipertensi Pada Masyarakat Di Kelurahan Mataiwoi Kecamatan Wua-Wua Kota Kendari. Miracle Journal Of Public Health, 1, 109-122.

Pical, F. I. 2011. Prevalensi dan Determinan Hipertensi di Posyandu Lansia Wilayah Kecamatan Pasar Rebo Jakarta Timur Tahun 2010. Skripsi. Fakultas Kesehatan Masyarakat Universitas Indonesia. Depok.

Pratiwi, I. P., et al. 2019. Analisa Hubungan Kebisingan Kereta Api Terhadap Peningkatan Tekanan Darah Karyawan Di Stasiun Bojong Gede Tahun 2018. PROMOTOR, 2, 191-198.

Putra, I. S., et al. 2019. Analisis Kemampuan Vegetasi Dalam Meredam Kebisingan. EUGENIA, 24.

Rachmawati, E., et al. 2019. Analisis Faktor-Faktor Yang Mempengaruhi Terjadinya Hipertensi Pada Pasien Lansia Di Kelurahan Semampir Kota Kediri Tahun 2018. Java Health Jounal, 6.

Rebar, C. R. 2017. Medical-Surgical Nursing-Concepts for Interprofessional Collaborative Car, Elsevier-Health Sciences Division. 
Resiana, F. 2014. Efektivitas Penghalang Vegetasi Sebagai Peredam Kebisingan Lalu Lintas Di Kawasan Pendidikan Jalan Ahmad Yani Pontianak. Jurnal Teknologi Lingkungan Lahan Basah, 3.

Reza, M. 2021. Hubungan Antara Merokok, Aktivitas Fisik dan Riwayat Keluarga dengan Kejadian Hipertensi pada Keluarga Mahasiswa FK USU. Skripsi. Program Studi Pendidikan dan Profesi Dokter Fakultas Kedokteran Universitas Sumatera Utara. Medan.

Riskesdas 2007. Riset Kesehatan Dasar.

Rizkiyanti, D. \& Trisnawati, Y. 2021. Faktor-Faktor Yang Berhubungan Dengan Hipertensi Pada Lansia. Jurnal Bina Cipta Husada, 17, 151-160.

Roscoe, J. T. 1975. Fundamental Research Statistics for the Behavioral Sciences [by] John T. Roscoe.

Roshifanni, S. 2016. Risiko Hipertensi Pada Orang Dengan Pola Tidur Buruk. Jurnal Berkala Epidemiologi, 4, 408-419.

Ryanti, S. D. 2019. Perubahan Tekanan Darah Pada Klien Hipertensi Yang Diberikan Aromaterapi Bunga Mawar. Skripsi. Program Studi Ilmu Keperawatan Universitas Muhammadiyah Malang. Malang.

Sartik, S., et al. 2017. Faktor-Faktor Risiko Dan Angka Kejadian Hipertensi Pada Penduduk Palembang. Jurnal Ilmu Kesehatan Masyarakat, 8.

Sarumaha, E. K. \& Diana, V. E. 2018. Faktor Risiko Kejadian Hipertensi Pada Usia Dewasa Muda Di Uptd Puskesmas Perawatan Plus Teluk Dalam Kabupaten Nias Selatan. Jurnal Kesehatan Global, 1, 70-77.

Sasmita, A. \& Andrio, D. 2017. Evaluasi Tingkat Kebisingan Di Bandara Sultan Syarif Kasim Ii Pekanbaru. WAKTU, 15, 30-35.

Satoto, H. F. 2018. Analisis Kebisingan Akibat Aktifitas Transportasi Pada Kawasan Pemukiman Jalan Sutorejo-Mulyorejo Surabaya. Heuristic, 15.

Setiati, S. 2015. Buku Ajar Ilmu Penyakit Dalam Jilid 2 Edisi 6, Jakarta, Interna Publishing.

Setiawan, A., et al. 2019. Hubungan Intensitas Kebisingan Dan Lama Kerja Dengan Kejadian Hipertensi Pada Tenaga Kerja Bagian Produksi Pt. Japfa Comfeed Indonesia Tbk. Jurnal Kesehatan Lingkungan: Jurnal dan Aplikasi Teknik Kesehatan Lingkungan, 15, 591-598.

Setiawan, M. F. 2010. Tingkat Kebisingan Pada Perumahan Di Perkotaan. Jurnal Teknik Sipil dan Perencanaan, 12. 
Sigarlaki, H. J. 2006. Karakteristik Dan Faktor Berhubungan Dengan Hipertensi Di Desa Bocor, Kecamatan Bulus Pesantren, Kabupaten Kebumen, Jawa Tengah, Tahun 2006. Makara, Kesehatan, 10, 78-88.

Sihombing, L. 2011. Kebisingan Pada Rumah Sakit dan Kenyamanan Pasien Rawat Inap di Rumah Sakit Umum Methodist Kota Medan Tahun 2010. Skripsi. Fakultas Kesehatan Masyarakat Universitas Sumatera Utara. Medan.

Singhal, S., et al. 2009. Effects of Workplace Noise on Blood Pressure and Heart Rate.

Smeltzer, S. C. \& Bare, B. G. Buku Ajar Keperawatan Medikal-Bedah, Vol. 3. 2002. EGC.

Smeltzer, S. C. \& Bare, B. G. 2013. Buku Keperawatan Medikal Bedah Brunner \& Suddarth. Jakarta: EGC.

Standar Nasional Indonesia. 2009. Metoda Pengukuran Intensitas Kebisingan di Tempat Kerja. Jakarta.

Suarya, I. M. \& I, N. S. 2015. Peranan Tembok Penyengker Didalam Mereduksi Kebisingan Akibat Suara Kendaraan Bermotor di Kelurahan Panjer Kecamatan Denpasar Selatan Kota Denpasar. Laporan Penelitian. Jurusan Arsitektur Fakultas Teknik Universitas Udayana. Denpasar.

Sudarta, I. W. 2013. Asuhan Keperawatan Klien Dengan Gangguan Sistem Cardiovaskuler. Yogyakarta: Gosyen Publishing.

Sugiyono 2008. Metode Penelitian Pendidikan:(Pendekatan Kuantitatif, Kualitatif Dan $R \& D$ ), Alfabeta.

Suma'mur, P. 2009. Higiene Perusahaan Dan Kesehatan Kerja (Hiperkes).

Surjono, B. 2012. Pengaruh Frekuensi Kebisingan Terhadap Tekanan Darah. Tesis. Program Pasca Sarjana Universitas Airlangga. Surabaya.

Suroto, W. 2010. Dampak Kebisingan Lalu Lintas Terhadap Permukiman Kota (Kasus Kota Surakarta). Journal of Rural and Development, 1.

Suryani, N. D. I. 2015. Analisis Pengaruh Tingkat Kebisingan Dan Getaran Kereta Api Terhadap Tekanan Darah Ibu Rumah Tangga di Pemukiman Pinggiran Rel Kereta Api Jalan Ambengan Surabaya. Skripsi. Fakultas Kesehatan Masyarakat. Surabaya.

Syaiful, S. \& Abidin, Z. 2017. Pengaruh Volume Lalu Lintas Terhadap Kebisingan Yang Ditimbulkan Kendaraan Bermotor. Simposium II UNIID 2017, 2, 229234. 
Tambunan, S. T. B. 2005. Kebisingan Di Tempat Kerja, Yogyakarta, Andi Offset.

Tindangen, B. F. E., et al. 2020. Faktor-Faktor Yang Berhubungan Dengan Kejadian Hipertensi Pada Guru Sekolah Dasar Di Kecamatan Tombariri Timur. KESMAS, 9.

Tjahjono, N. \& Nugroho, I. Tanaman Hias Sebagai Peredam Kebisingan. Conference on Innovation and Application of Science and Technology (CIASTECH), 2018. 703-710.

Tjiptoherijanto, P. 2001. Proyeksi Penduduk, Angkatan Kerja, Tenaga Kerja, Dan Peran Serikat Pekerja Dalam Peningkatan Kesejahteraan. Majalah Perencanaan Pembangunan, 23, 1-10.

Triyanto, E. 2014. Pelayanan Keperawatan Bagi Penderita Hipertensi Secara Terpadu. Yogyakarta: Graha Ilmu.

Van Kempen, E. \& Babisch, W. 2012. The Quantitative Relationship between Road Traffic Noise and Hypertension: A Meta-Analysis. Journal of hypertension, 30, 1075-1086.

Wafiroh, A. H. 2013. Pengukuran Tingkat Kebisingan Di Lingkungan Smpn 2 Jember.

Wicaksono, S. 2019. Angka Kejadian Peningkatan Tekanan Darah (Hipertensi) Pada Lansia Di Dusun 1 Desa Kembangseri Kecamatan Talang Empat Bengkulu Tengah Tahun 2015. Jurnal Kedokteran RAFLESIA, 5, 1-6.

Wijaya, A. S. \& Putri, Y. M. 2013. Keperawatan Medikal Bedah (Keperawatan Dewasa).

WHO. 2013.

WHO. 1999. Guidelines for Community Noise. Geneva. WHO.

WHO. 1980. Environmental Health Criteria 12 (Noise). Geneva. WHO.

Worldometer. Dari: https://www.worldometers.info/world-population/ [Diakses 24 April 2020].

Worldometer. Dari: https://www.worldometers.info/population/countries-in-asiaby-population/ [Diakses 24 April 2020].

Yonata, A. \& Pratama, A. S. P. 2016. Hipertensi Sebagai Faktor Pencetus Terjadinya Stroke. Jurnal Majority, 5, 17-21. 
Yosieguspa, Y. 2015. Pengaruh Vegetasi Dalam Meredam Tingkat Kebisingan Lalu Lintas Jalan Raya Di Kawasan Taman Wisata Alam (Twa) Punti Kayu Palembang. Jurnal Dampak, 12, 104-113.

Yuliana, T., et al. 2017. Perbedaan Tekanan Darah Berdasarkan Status Merokok (Studi Di Rusun Rawa Sawah Besar Kaligawe Semarang). Karya Ilmiah, 6. 